УДК 004.421:004.65:378.147

Вакалюк Тетяна Анатоліївна

кандидат педагогічних наук, доцент, доцент кафедри прикладної математики та інформатики

Житомирський державний університет імені Івана Франка, м. Житомир, Україна

ORCID ID 0000-0001-6825-4697

neota@zu.edu.ua

Коротун Ольга Володимирівна

кандидат педагогічних наук, доцент кафедри комп'ютерних наук

Житомирський державний технологічний університет, м. Житомир, Україна

ORCID ID 0000-0003-2240-7891

olgavl.korotun@gmail.com

Антонюк Дмитро Сергійович

кандидат педагогічних наук, доцент кафедри інженерії програмного забезпечення

Житомирський державний технологічний університет, м. Житомир, Україна

ORCID ID 0000-0001-7496-3553

dmitry_antonyuk@zu.edu.ua

\title{
ДОБІР ХМАРО ОРІЕНТОВАНИХ ЗАСОБІВ НАВЧАННЯ БАЗ ДАНИХ МАЙБУТНІХ ФАХІВЦІВ 3 ІНФОРМАЦІЙНИХ ТЕХНОЛОГІЙ
}

\begin{abstract}
Анотація. У статті здійснено добір хмаро орієнтованих засобів навчання баз даних студентів закладів вищої освіти методом експертного оцінювання. Для цього виокремлено критерії та відповідні показники добору зазначених засобів навчання. Із запропонованих хмаро орієнтованих засобів навчання баз даних (Amazon RDS, Google Cloud SQL, Heroku PostgreSQL, Microsoft SQL Azure, Oracle Database Cloud Service, Rackspace Cloud Databases, SQLite Viewer) було обрано три методом експертного оцінювання, до якого було залучено викладачів, завідувачів кафедр і деканів закладів вищої освіти України, які мають досвід роботи в закладах вищої освіти та безпосередньо пов'язані 3 навчанням баз даних. Проведено порівняльний аналіз наявних хмаро орієнтованих засобів навчання баз даних, а саме: Google Cloud SQL, Microsoft SQL Azure, SQLite Viewer with Google Drive, що дозволив визначити функціонально-дидактичний та організаційний критерії. Розглянуто можливості застосування таких хмаро орієнтованих засобів навчання студентів у закладах вищої освіти. До кожного з зазначених критеріїв було виокремлено відповідні показники. До функціонально-дидактичного критерію належать: можливість створення, редагування та видалення таблиць у базах даних; визначення первинних та зовнішніх ключів у таблиці; створення зв'язків між таблицями баз даних; модифікація даних у таблицях баз даних; можливість аналізу результатів та помилок у запитах. До організаційного критерію належать такі показники: доступність (безкоштовна версія; термін дії безкоштовної версії); підтвердження фінансової спроможності користувача; зручність інтерфейсу. У результаті застосування методу експертного оцінювання з'ясовано, що найбільш доцільним хмаро орієнтованим засобом навчання баз даних студентів закладів вищої освіти за проявом усіх критеріїв $\epsilon$ SQLite Viewer with Google Drive.
\end{abstract}

Ключові слова: добір; критерії добору; хмаро орієнтовані засоби; бази даних; студенти закладів вищої освіти.

\section{1. ВСТУП}

Постановка проблеми. Процес підготовки майбутніх фахівців у закладах вищої освіти (ЗВО) передбачає обов'язкове вивчення баз даних (БД) чи то окремою дисципліною, як у випадках підготовки майбутніх учителів інформатики та інженерівпрограмістів, чи то окремим модулем дисципліни "Інформатика" студентів інших спеціальностей. У навчанні БД викладач робить акцент на особливостях технологій БД, щоб студенти розуміли основні тенденції розвитку сучасних БД, переваги й недоліки в 
ïx використанні, специфіку роботи в системах керування базами даних (СКБД) тощо. Отримані знання, уміння й навички з БД необхідні майбутнім фахівцям у їхній професійній діяльності, зокрема при проведенні уроків інформатики з теми "Системи керування базами даних"; підготовці учнів до олімпіад та конкурсів у номінації "Бази даних"; використанні освітніх БД; адмініструванні наявних БД у закладах загальної середньої освіти (З3СО), адмініструванні наявних БД на фірмах тощо.

Для підвищення ефективності освітнього процесу в навчанні баз даних та вдосконалення професійної підготовки майбутніх фахівців викладачам 3ВО варто використовувати новітні засоби навчання, зокрема й хмаро орієнтовані засоби навчання окремих дисциплін. Застосування таких технологій навчання в освітньому процесі наразі $\epsilon$ актуальним питанням теорії та методики використання інформаційнокомунікаційних технологій (ІКТ) в освіті.

Аналіз останніх досліджень і публікацій. У ряді наукових праць висвітлено теоретичні та практичні основи застосування хмарних обчислень в освіті: В. Ю. Биков [1], С. Г. Литвинова [2], Ю. Г. Носенко [3], В. П. Олексюк [4], М. В. Попель [5], С. О. Семеріков [6], А. М. Стрюк [7], М. П. Шишкіна [8] та ін. Суттєвий внесок у теорію й практику впровадження і використання хмарних сервісів в освітньому процесі зробили й такі зарубіжні вчені: Х. Ф. Альделейай (H. F. Aldheleai), Н. Ангелова (N. Angelova), К. Р. Аніл Кумар (K. R. Anil Kumar), Р. Гурунатх (R. Gurunath), Д. Е. Дін (D. E. Dean), Г. Кірякова (G. Kiryakova), Г. Л. Пратт (G. L. Pratt), В. В. Рябов (V. V. Riabov), М. Убайдулла (M. Ubaidullah), К. Хеввіт (Carl Hewwit) та ін. Основні поняття теорії баз даних, процес нормалізації БД, методологію проектування БД, архітектуру БД, сучасні СКБД, мову запитів SQL та питання їх навчання у ЗВО розглядали такі вітчизняні науковці: Г. А. Гайна [9], Л. С. Глоба [10], В. М. Гужва [11], І. О. Завадський [12], В. В. Осадчий [13], О. К. Пандорін [14], С. В. Шаров [13] та ін. Однак недостатньо уваги дослідники приділяють питанню впровадження та використання хмарних обчислень у навчанні баз даних. Критерії та показники добору різних ІКТ для використання в освітній діяльності розглядали В. Ю. Биков [15], В. М. Дем'яненко [16], К. Р. Колос [17], Г. П. Лаврентьєва [16], Л. А. Лупаренко [15], [18], О. М. Спірін [1], М. П. Шишкіна [16] та ін.

Метою статті $є$ здійснити добір хмаро орієнтованих засобів навчання баз даних студентів закладів вищої освіти методом експертного оцінювання.

\section{2. МЕТОДИКА ДОСЛІДЖЕННЯ}

Для здійснення добору хмаро орієнтованих засобів навчання баз даних студентів закладів вищої освіти було застосовано метод експертного оцінювання [19].

Відповідно до цього методу хмаро орієнтовані засоби навчання (ХОЗН) баз даних нумеруються в порядку зростання або спадання за певною ознакою для подальшого їх ранжування. Опитування експертів здійснювалось у два етапи. Розглянемо їх.

Перший етап опитування експертів. Фахівцям було запропоновано оцінити 7 загальновідомих ХОЗН, що можуть використовуватися для навчання БД студентів закладів вищої освіти. 3 метою експертного оцінювання було залучено фахівців цього профілю - викладачів, завідувачів кафедр і деканів 3ВО України, які мають досвід та безпосередньо пов'язані з навчанням БД (всього 12 осіб). Експертами виступили вказані категорії професорсько-викладацького складу таких ЗВО України: Дрогобицький державний педагогічний університет імені Івана Франка, ДВНЗ "Криворізький державний педагогічний університет", ДВНЗ "Переяслав-Хмельницький державний педагогічний університет імені Григорія Сковороди", Житомирський 
державний університет імені Івана Франка та Уманський державний педагогічний університет імені Павла Тичини.

У межах нашого дослідження вони скористалися бальною системою оцінки, запропонованою Т. А. Вакалюк та О. М. Спіріним [19], згідно 3 якою для кількості 7 $\mathrm{XO} 3 \mathrm{H}$ :

- максимальну оцінку 7 отримає найбільш значуща у використанні ХОЗН;

- мінімальну оцінку 1 отримає найменш значуща у використанні ХОЗН.

Щоб встановити існування об'єктивного погодження між експертами, визначається коефіцієнт конкордації Кенделла [20] за такою формулою:

$$
\begin{array}{r}
W=\frac{S\left(d^{2}\right)}{S_{\max }\left(d^{2}\right)}=\frac{12 \cdot S\left(d^{2}\right)}{m^{2}\left(n^{3}-n\right)}, \\
S\left(d^{2}\right)=\sum_{j=1}^{n} d_{j}^{2} ; \\
d_{j}=S_{j}-0,5 \cdot m \cdot(n+1) ; \\
S_{j}=\sum_{i=1}^{m} R_{i, j} ;
\end{array}
$$

$S_{j}$ - сумарний ранг $j$-го показника (головний параметр оцінювання значущості показника); $j=1,2,3 \ldots n ; n$ - кількість показників; $m$ - кількість експертів; $R_{i, j}$ - ранг јго показника, визначений і-тим експертом.

Після проведення необхідних обчислень 3 використанням експериментальних даних одержуємо певне значення коефіцієнта конкордації Кенделла W. У випадку суттєвої різниці від нуля результатів обчислення визначаємо існування об'єктивного погодження між експертами ( $\mathrm{W}=0$ - зв' язок між ранжуванням експертів відсутній, $\mathrm{W}=1$ - ранжування повністю збігаються), сумарні ранги є досить об'єктивними.

На другому етапі дослідження група фахівців була залучена для визначення найбільш значущих хмаро орієнтованих засобів навчання баз даних студентів закладів вищої освіти згідно визначених критеріїв.

Прояв кожного з поданих критеріїв оцінювався для кожного із зазначених хмаро орієнтованих засобів навчання баз даних студентів закладів вищої освіти за такою шкалою: 0 балів - показник відсутній; 1 бал - показник більше не наявний, ніж наявний; 2 бали - показник більше наявний, ніж не наявний; 3 бали - показник повністю наявний.

Показник вважається позитивним, якщо значення середнього арифметичного значень усіх показників даного критерію не менше ніж 1,5.

При цьому критерій вважається:

- недостатньо проявленим, якщо більше ніж 50\% його показників є негативними;

- критично проявленим, якщо 50\%-55\% його показників є позитивними;

- достатньо проявленим, якщо 56\%-75\% його показників $є$ позитивними;

- і високо проявленим, якщо 76\%-100\% його показників є позитивними [21].

Дослідження проводилось у рамках НДР №0117U001063 «Хмарні технології у навчанні майбутніх вчителів інформатики» кафедри прикладної математики та інформатики Житомирського державного університету імені Івана Франка.

\section{3 РЕЗУЛЬТАТИ ДОСЛІДЖЕННЯ}

Упровадження ХОЗН дозволяє суб'єктам навчання отримати встановлене та налаштоване програмне забезпечення для роботи з БД. Основними перевагами використання ХОЗН баз даних у $3 \mathrm{BO}$ є: висока масштабованість (постійно 
відслідковується робоча завантаженість), зниження витрат на покупку ПЗ (СКБД), швидкість надання послуг, надійність та захищеність з боку провайдера хмарних обчислень.

Для виокремлення доцільного ХОЗН БД студентів скористаємося методом експертного оцінювання, який детально описано вище.

Для формування списку пропонованих ХОЗН було проведено опитування викладачів та науковців, що безпосередньо пов'язані з викладанням БД у ЗВО, на конференціях, семінарах, круглих столах з метою встановлення, якими ХОЗН БД користуються у різних ЗВО. У результаті було сформовано список найбільш використовуваних ХОЗН БД у ЗВО України (див. табл. 1).

На першому етапі експертам було запропоновано пройти опитування 3 метою ранжування ХОЗН БД (див. табл.1), результати якого представлені в табл. 2.

Табличя 1.

\section{Картка опитування експерта щодо визначення доцільного ХОЗН БД у підготовці студентів закладів вищої освіти}

Шановний експерте!

Просимо здійснити оцінювання запропонованих ХОЗН за шкалою від 1 (мінімальна оцінка) до 7 (максимальна оцінка), де 7 надається найвагомішому ХОЗН БД студентів закладів вищої освіти, 1 - найменш вагомому.

\begin{tabular}{|l|l|l|}
\hline № & \multicolumn{1}{|c|}{ Назва ХO3H } & Ваша оцінка \\
\hline 1. & Amazon RDS & \\
\hline 2. & Google Cloud SQL & \\
\hline 3. & Heroku PostgreSQL & \\
\hline 4. & Microsoft SQL Azure & \\
\hline 5. & Oracle Database Cloud Service & \\
\hline 6. & Rackspace Cloud Databases & \\
\hline 7. & SQLite Viewer & \\
\hline
\end{tabular}

Таблиия 2

Ранжування ХОЗН БД у підготовці студентів закладів вищої освіти

\begin{tabular}{|c|c|c|c|c|c|c|c|}
\hline $\begin{array}{l}\text { №3 } \\
\text { екс. }\end{array}$ & $\begin{array}{c}\text { Amazon } \\
\text { RDS }\end{array}$ & $\begin{array}{c}\text { Google } \\
\text { Cloud } \\
\text { SQL }\end{array}$ & $\begin{array}{c}\text { Heroku } \\
\text { PostgreSQL }\end{array}$ & $\begin{array}{c}\text { Microsoft } \\
\text { SQL Azure }\end{array}$ & $\begin{array}{c}\text { Oracle } \\
\text { Database } \\
\text { Cloud } \\
\text { Service }\end{array}$ & $\begin{array}{c}\text { Rackspace } \\
\text { Cloud } \\
\text { Databases }\end{array}$ & $\begin{array}{c}\text { SQLite } \\
\text { Viewer }\end{array}$ \\
\hline $\mathbf{1 .}$ & 4 & 5 & 3 & 6 & 2 & 1 & 7 \\
\hline $\mathbf{2 .}$ & 5 & 4 & 2 & 7 & 1 & 3 & 6 \\
\hline $\mathbf{3 .}$ & 3 & 6 & 4 & 5 & 2 & 1 & 7 \\
\hline $\mathbf{4 .}$ & 1 & 5 & 4 & 7 & 2 & 3 & 6 \\
\hline $\mathbf{5 .}$ & 4 & 5 & 3 & 6 & 1 & 2 & 7 \\
\hline $\mathbf{6 .}$ & 3 & 6 & 4 & 7 & 1 & 2 & 5 \\
\hline $\mathbf{7 .}$ & 4 & 6 & 1 & 5 & 2 & 3 & 7 \\
\hline $\mathbf{8 .}$ & 4 & 5 & 2 & 7 & 3 & 1 & 6 \\
\hline $\mathbf{9 .}$ & 5 & 6 & 1 & 4 & 2 & 3 & 7 \\
\hline $\mathbf{1 0 .}$ & 2 & 5 & 3 & 7 & 4 & 1 & 6 \\
\hline $\mathbf{1 1 .}$ & 4 & 6 & 1 & 5 & 3 & 2 & 7 \\
\hline $\mathbf{1 2 .}$ & 4 & 5 & 2 & 6 & 3 & 1 & 7 \\
\hline $\boldsymbol{S}$ & $\mathbf{4 3}$ & $\mathbf{6 4}$ & $\mathbf{3 0}$ & $\mathbf{7 2}$ & $\mathbf{2 6}$ & $\mathbf{2 3}$ & $\mathbf{7 8}$ \\
\hline $\boldsymbol{d}$ & $\mathbf{- 5}$ & $\mathbf{1 6}$ & $\mathbf{- 1 8}$ & $\mathbf{2 4}$ & $\mathbf{- 2 2}$ & $\mathbf{- 2 5}$ & $\mathbf{3 0}$ \\
\hline
\end{tabular}


Провівши обчислення за формулами (1) - (4) за даними таблиці 2, маємо:

$$
\begin{aligned}
& S\left(d^{2}\right)=(-5)^{2}+16^{2}+(-18)^{2}+24^{2}+(-22)^{2}+(-25)^{2}+30^{2}=3190 \\
& W=\frac{12 \cdot 3190}{12^{2} \cdot\left(7^{3}-7\right)}=0,79
\end{aligned}
$$

Отже, коефіцієнт конкордації Кенделла $\mathrm{W}=0,79$ відрізняється від нуля, а тому між експертами існує об'єктивне погодження.

У результаті було обрано три ХОЗН баз даних студентів, а caмe: Google Cloud SQL, Microsoft SQL Azure, SQLite Viewer with Google Drive. Розглянемо можливості застосування таких ХОЗН БД у підготовці студентів закладів вищої освіти.

Google Cloud SQL - ХОЗН БД від Google, створений на платформі Google Cloud для роботи зі СКБД MySQL. Цей засіб дозволяє створювати, формувати i використовувати реляційні бази даних зі своїми додатками на основі App Engine додатків, написаних мовою програмування Python.

Основні особливості цього ХОЗН:

- легкість у використанні - багатий графічний інтерфейс користувача враховує створення, формування, управління і контроль баз даних;

- повністю керований сервіс - не потрібно турбуватися про реплікації, налаштування та інші схожі завдання бази даних, усе це виконує сервіс;

- високодоступний - сервіс залишається доступним, навіть якщо центр даних стає недоступним;

- забезпечення захисту даних БД - запис даних у бази серверів Google зашифровані, тому доступ дозволений тільки 3 авторизованих IP-адрес та відбувається через SSL-протокол.

Для проведення курсу навчання БД існує можливість створити БД для кожного студента, де той може виконувати практичні завдання викладача. Останній має інформацію про стан робіт усіх студентів і може в будь-який момент здійснити перевірку. Можливості прив'язки облікових записів до проекту Google Cloud SQL також можуть сприяти більш зручному і швидкому віддаленому навчанню технологій СКБД. Даний ХОЗН має обмежений термін дії безкоштовної версії. Тому для повноцінного використання ЗВО має придбати ліцензію.

Microsoft SQL Azure - ХОЗН БД від Microsoft, розміщений на платформі Microsoft Azure. SQL Azure - проекція традиційної СКБД Microsoft SQL Server на хмару, що дає змогу для роботи з базою даних. Цей ХОЗН дозволяє зберігати структуровані й неструктуровані дані, виконувати реляційні запити, а також надає функціонал для здійснення пошуку, створення аналітичних звітів, інтеграції та синхронізації даних. SQL Azure має високий рівень безпеки з вбудованим захистом даних, самовідновленням і системою резервного копіювання. Робота 3 SQL Azure побудована на основі трьох механізмів - облікового запису, сервера та БД. Обліковий запис є власником одного або більше серверів. Сервер - це логічна концепція, аналогічна Master DB, яка має одну або більше бази даних, містить метадані про базу даних і дані про іiї використання. Кожна БД у рамках сервера зберігає стандартні SQL об'єкти: користувачів, таблиці, індекси та інше. Для вказаного ХОЗН термін дії використання безкоштовної версії обмежений. Тому для повноцінного його застосування 3ВО повинен придбати ліцензію.

SQLite Viewer with Google Drive - ХОЗН, синхронізований із сервісами Google, який дозволяє відкривати базу даних SQLite і керувати нею. Для використання SQLite Viewer with Google Drive у навчанні БД викладачу та студенту необхідно:

1. Додати сервіс SQLite Viewer у власний обліковий запис Google через будь-який браузер (Chrome, IE10+, Firefox, Safari тощо). 
2. Зайти у свій акаунт Google.

3. Зайти на сервіс Google Диск.

4. Натиснути кнопку "Створити", обрати "SQLite Viewer" (рис. 1).

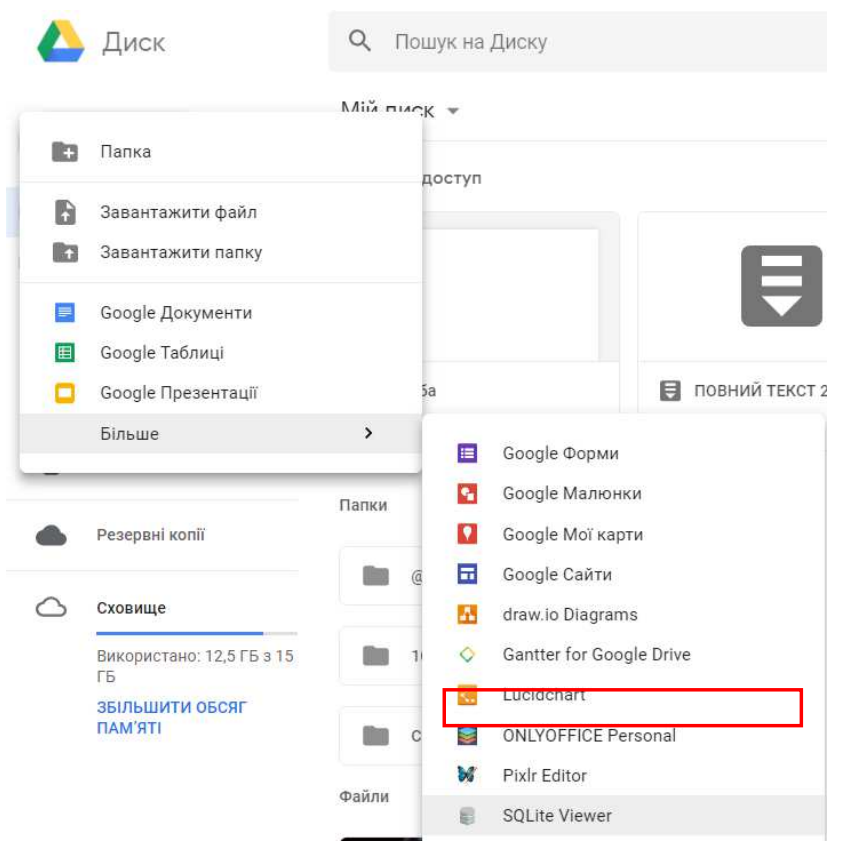

Puc. 1. Доступ до сервісу SQLite Viewer з Google Диск

5. Після відкриття веб-сторінки SQLite Viewer with Google Drive, завантажити файл БД SQLite для перегляду та роботи з ним iз Google Диск, 3 комп’ютера або перетягнути з ПК у форматі sqlite (рис. 2).

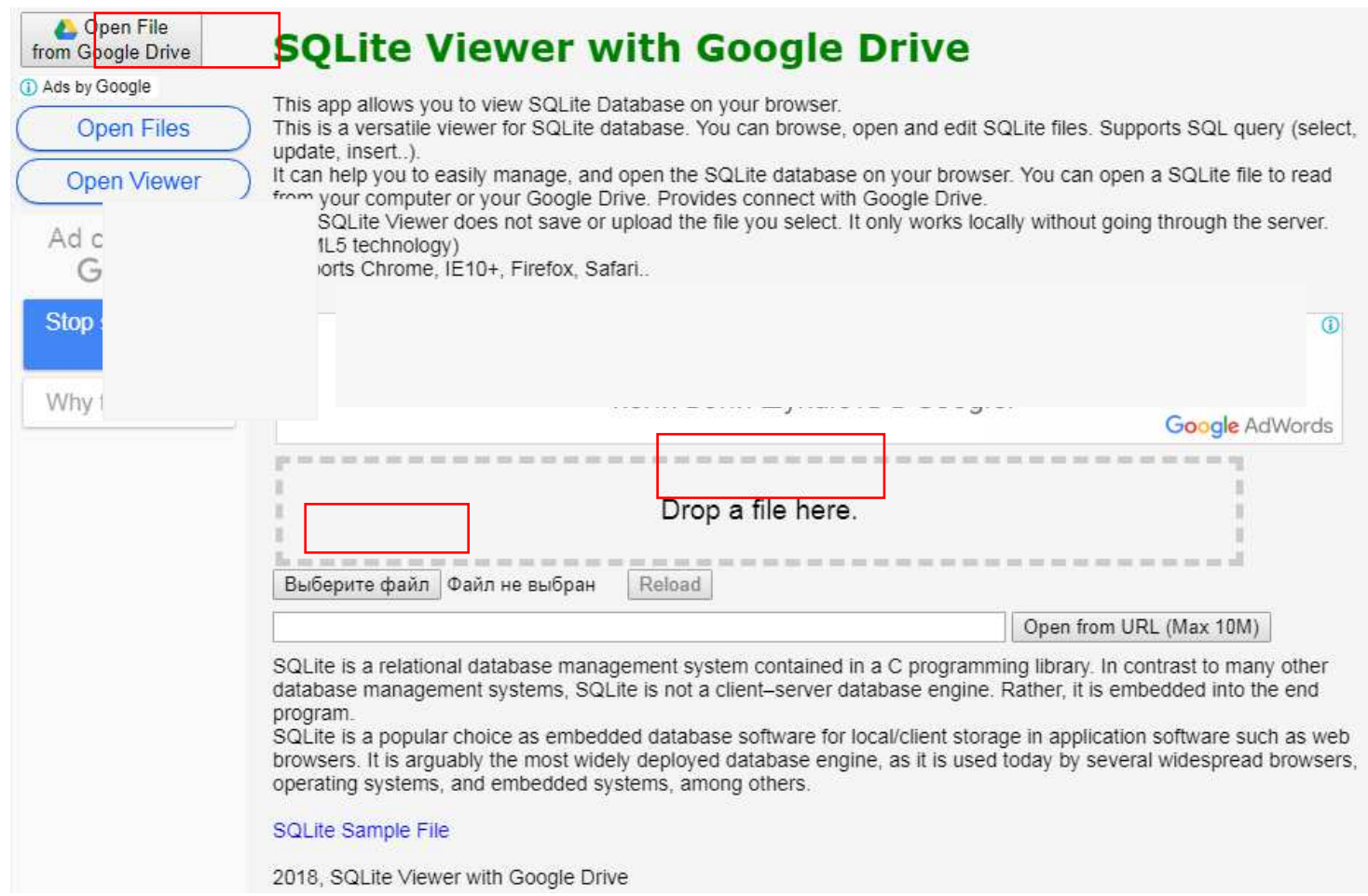

Pис. 2. Веб-сторінка SQLite Viewer with Google Drive 
У SQLite Viewer with Google Drive можна відкривати, переглядати та редагувати файли БД SQLite. У цьому сервісі є можливість виконувати різні команди для роботи 3 таблицями (наприклад, створення, видалення) та записами (наприклад, додавання, редагування, видалення, вибірка) таблиць БД, які створені в СКБД SQLite.

SQLite - це безкоштовна система управління реляційною базою даних із відкритим вихідним кодом, візуальний інструмент для створення, проектування та редагування файлів БД. Саме тому викладачі ЗВО мають можливість використовувати безкоштовно у навчальній діяльності зазначений ХОЗН.

Основні команди для користувачів: створення файлів баз даних; створення, визначення типів полів, наповнення, редагування та видалення таблиць; створення, визначення та видалення індексів; перегляд, редагування, додавання та видалення записів; пошук записів; імпорт і експорт записів у текстовий файл; імпорт і експорт таблиць з/в CSV-файлів; імпорт і експорт БД з/в файлів SQL; створення SQL запитів тощо.

Для другого emany опитування експертів визначено такі критерії та показники добору ХОЗН БД у підготовці студентів закладів вищої освіти:

- функціонально-дидактичний: можливість створення, редагування та видалення таблиць у БД; визначення первинних та зовнішніх ключів у таблиці; створення зв'язків між таблицями БД; модифікація даних у таблицях БД; можливість аналізу результатів та помилок у запитах;

- організаційний: доступність (безкоштовна версія; термін дії безкоштовної версії); підтвердження фінансової спроможності користувача; зручність інтерфейсу.

Функціонально-дидактичний критерій характеризує функціональну та дидактичну складову ХОЗН баз даних у підготовці студентів закладів вищої освіти, основою його є засвоєння знань загальної структури мови запитів SQL та практичних умінь і навичок використання цієї мови для роботи з об'єктами БД відповідно до робочої програми дисципліни «Бази даних». Показники цього критерію:

- можливість створення, редагування та видалення таблищь у БД визначає наявність у ХO3 можливості використання команд SQL для створення, редагування та видалення таблиць у БД;

- визначення первинних та зовнішніх ключів у таблиці - наявність у ХОЗН створення первинних та зовнішніх ключів у таблицях БД;

- створення зв'язків між таблииями БД - наявність у ХОЗН можливості налаштування зв'язків між таблицями БД;

- модифікація даних у таблищях БД - наявність у ХОЗН можливості додавати, редагувати та видаляти дані в таблицях БД;

- можливість аналізу результатів та помилок у запитах - наявність у ХОЗН можливості аналізу результатів виконання запитів та помилок при написанні запитів.

Результати проміжних даних експертного опитування за дидактичним критерієм подані в табл. 3-5.

Таблиия 3

Результати оцінювання XОЗН Google Cloud SQL за функціонально-дидактичним критерісм

\begin{tabular}{|c|c|c|c|c|c|}
\hline \multirow{2}{*}{$\begin{array}{c}\text { Номер } \\
\text { експерта }\end{array}$} & \multicolumn{5}{|c|}{ Кількість балів за показник № } \\
\hline & $\mathbf{1}$ & 2 & 3 & 4 & 5 \\
\hline 1 & 3 & 3 & 3 & 2 & 2 \\
\hline 2 & 3 & 3 & 3 & 3 & 2 \\
\hline 3 & 3 & 3 & 3 & 3 & 3 \\
\hline
\end{tabular}




\begin{tabular}{|c|c|c|c|c|c|}
\hline $\mathbf{4}$ & 2 & 3 & 2 & 2 & 2 \\
\hline $\mathbf{5}$ & 3 & 3 & 3 & 3 & 2 \\
\hline $\mathbf{6}$ & 3 & 2 & 3 & 3 & 3 \\
\hline $\mathbf{7}$ & 3 & 3 & 3 & 3 & 2 \\
\hline $\mathbf{8}$ & 3 & 2 & 3 & 2 & 2 \\
\hline $\mathbf{9}$ & 3 & 3 & 3 & 2 & 3 \\
\hline $\mathbf{1 0}$ & 2 & 2 & 3 & 3 & 3 \\
\hline $\mathbf{1 1}$ & 2 & 3 & 3 & 3 & 3 \\
\hline $\mathbf{1 2}$ & 3 & 3 & 3 & 3 & 2 \\
\hline Сер. арифм. & $\mathbf{2 , 7 5}$ & $\mathbf{2 , 7 5}$ & $\mathbf{2 , 9 2}$ & $\mathbf{2 , 6 7}$ & $\mathbf{2 , 4 2}$ \\
\hline
\end{tabular}

Табличя 4

Результати оцінювання ХОЗН Microsoft SQL Azure за функціональнодидактичним критерієм

\begin{tabular}{|c|c|c|c|c|c|}
\hline \multirow{2}{*}{$\begin{array}{c}\text { Номер } \\
\text { експерта }\end{array}$} & $\mathbf{5}$ & $\mathbf{3}$ & $\mathbf{4}$ & $\mathbf{5}$ \\
\hline $\mathbf{1}$ & $\mathbf{1}$ & $\mathbf{2}$ & 2 & 3 & 3 \\
\hline $\mathbf{2}$ & 3 & 3 & 3 & 3 & 3 \\
\hline $\mathbf{3}$ & 3 & 3 & 3 & 3 & 3 \\
\hline $\mathbf{4}$ & 2 & 3 & 2 & 3 & 3 \\
\hline $\mathbf{5}$ & 3 & 3 & 3 & 2 & 3 \\
\hline $\mathbf{6}$ & 3 & 3 & 3 & 3 & 3 \\
\hline $\mathbf{7}$ & 2 & 3 & 2 & 3 & 3 \\
\hline $\mathbf{8}$ & 2 & 3 & 3 & 2 & 2 \\
\hline $\mathbf{9}$ & 3 & 2 & 3 & 2 & 3 \\
\hline $\mathbf{1 1}$ & 3 & 3 & 3 & 3 & 3 \\
\hline $\mathbf{1 2}$ & 3 & 2 & 2 & 3 & 3 \\
\hline Сер. арифм. & $\mathbf{2 , 7 5}$ & $\mathbf{2 , 8 3}$ & $\mathbf{2 , 6 7}$ & $\mathbf{2 , 7 5}$ & $\mathbf{2 9 2}$ \\
\hline
\end{tabular}

Таблиия 5

Результати оцінювання ХОЗН SQLite Viewer with Google Drive за функціональнодидактичним критерієм

\begin{tabular}{|c|c|c|c|c|c|}
\hline \multirow{2}{*}{$\begin{array}{c}\text { Номер } \\
\text { експерта }\end{array}$} & \multicolumn{5}{|c|}{ Кількість балів за показник № } \\
\hline & 1 & 2 & 3 & 4 & 5 \\
\hline 1 & 3 & 3 & 3 & 3 & 3 \\
\hline 2 & 3 & 3 & 3 & 3 & 3 \\
\hline 3 & 3 & 2 & 2 & 3 & 3 \\
\hline 4 & 2 & 3 & 3 & 2 & 3 \\
\hline 5 & 3 & 2 & 3 & 3 & 2 \\
\hline 6 & 3 & 3 & 3 & 3 & 3 \\
\hline 7 & 3 & 3 & 3 & 3 & 3 \\
\hline 8 & 3 & 3 & 3 & 2 & 3 \\
\hline 9 & 3 & 3 & 3 & 3 & 2 \\
\hline 10 & 3 & 3 & 3 & 3 & 3 \\
\hline 11 & 3 & 3 & 2 & 2 & 3 \\
\hline 12 & 3 & 2 & 2 & 3 & 3 \\
\hline $\begin{array}{c}\text { Середнє } \\
\text { арифм. }\end{array}$ & 2,92 & 2,75 & 2,75 & 2,75 & 2,83 \\
\hline
\end{tabular}

Висвітлимо результати за показниками функціонально-дидактичного критерію для кожного ХO3 у навчанні БД (табл. 6). 
Таблиия 6

Функціонально-дидактичний критерій та його показники добору ХОЗН БД у підготовці студентів закладів вищої освіти

\begin{tabular}{|c|c|c|c|c|c|c|}
\hline $\begin{array}{l}\text { Показники № } \\
\text { хо3 у } \\
\text { навчанні БД }\end{array}$ & 1 & 2 & 3 & 4 & 5 & 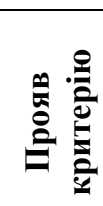 \\
\hline Google Cloud SQL & 2,75 & 2,75 & 2,92 & 2,67 & 2,42 & $100 \%$ \\
\hline Microsoft SQL Azure & 2,75 & 2,83 & 2,67 & 2,75 & 2,92 & $100 \%$ \\
\hline $\begin{array}{l}\text { SQLite Viewer with } \\
\text { Google Drive }\end{array}$ & 2,92 & 2,75 & 2,75 & 2,75 & 2,83 & $100 \%$ \\
\hline
\end{tabular}

Організаційний критерій характеризує використання ХОЗН БД з технічного боку. Його показники:

- доступність - одночасно перевірялась наявність у ХОЗ безкоштовної версії для навчання БД студентів закладів вищої освіти та термін дії безкоштовної версії;

- підтвердження фінансової спроможності користувача - характеризує в ХОЗ відсутність указування персональних даних про фінансове становище користувача для подальшого стягування з нього коштів за використання такого засобу;

- зручність використання - характеризує зручність та зрозумілість інтерфейсу ХОЗ для використання у навчанні БД.

Результати проміжних обрахунків експертного опитування за організаційним критерієм представлені в таблицях 7-9.

Таблиия 7

Результати оцінювання XO3H Google Cloud SQL за організаційним критерісм

\begin{tabular}{|c|c|c|c|c|}
\hline \multirow[b]{2}{*}{ Номер експерта } & \multicolumn{4}{|c|}{ Кількість балів за показник № } \\
\hline & $\mathbf{1 a}$ & 10 & 2 & 3 \\
\hline 1 & 3 & 0 & 0 & 1 \\
\hline 2 & 3 & 1 & 1 & 2 \\
\hline 3 & 2 & 2 & 0 & 0 \\
\hline 4 & 3 & 0 & 0 & 1 \\
\hline 5 & 3 & 2 & 0 & 2 \\
\hline 6 & 3 & 2 & 0 & 1 \\
\hline 7 & 3 & 0 & 0 & 2 \\
\hline 8 & 2 & 2 & 1 & 2 \\
\hline 9 & 3 & 1 & 0 & 1 \\
\hline 10 & 3 & 2 & 0 & 3 \\
\hline 11 & 3 & 1 & 1 & 1 \\
\hline 12 & 3 & 2 & 0 & 1 \\
\hline Середнє арифм. & 2,83 & 1,25 & 0,25 & 1,42 \\
\hline
\end{tabular}


Таблиия 8

Результати оцінювання ХOЗН Microsoft SQL Azure за організаційним критерісм

\begin{tabular}{|c|c|c|c|c|}
\hline \multirow{2}{*}{ Номер експерта } & \multicolumn{5}{|c|}{ Кількість балів за показник № } \\
\cline { 2 - 5 } & $\mathbf{1 a}$ & $\mathbf{1 0}$ & $\mathbf{2}$ & $\mathbf{3}$ \\
\hline $\mathbf{1}$ & 3 & 1 & 0 & 2 \\
\hline $\mathbf{2}$ & 3 & 0 & 0 & 2 \\
\hline $\mathbf{3}$ & 3 & 2 & 1 & 1 \\
\hline $\mathbf{5}$ & 3 & 1 & 0 & 1 \\
\hline $\mathbf{6}$ & 3 & 2 & 0 & 1 \\
\hline $\mathbf{7}$ & 3 & 1 & 0 & 2 \\
\hline $\mathbf{8}$ & 3 & 0 & 0 & 1 \\
\hline $\mathbf{9}$ & 2 & 1 & 0 & 2 \\
\hline $\mathbf{1 0}$ & 3 & 2 & 0 & 3 \\
\hline $\mathbf{1 1}$ & 3 & 1 & 0 & 2 \\
\hline $\mathbf{1 2}$ & 3 & 1 & 0 & $\mathbf{1 , 7 5}$ \\
\hline Середнс арифм. & $\mathbf{2 , 9 2}$ & 0 & $\mathbf{0 , 1 7}$ & \\
\hline
\end{tabular}

Таблиия 9

Результати оцінювання XОЗН SQLite Viewer with Google Drive за організаційним критерієм

\begin{tabular}{|c|c|c|c|c|}
\hline \multirow{2}{*}{ Номер експерта } & \multicolumn{5}{|c|}{ Кількість балів за показник № } \\
\cline { 2 - 5 } & $\mathbf{1 a}$ & $\mathbf{1 0}$ & $\mathbf{2}$ & $\mathbf{3}$ \\
\hline $\mathbf{1}$ & 3 & 3 & 3 & 2 \\
\hline $\mathbf{3}$ & 3 & 3 & 3 & 3 \\
\hline $\mathbf{4}$ & 2 & 3 & 3 & 2 \\
\hline $\mathbf{5}$ & 3 & 3 & 3 & 3 \\
\hline $\mathbf{6}$ & 3 & 3 & 3 & 2 \\
\hline $\mathbf{7}$ & 3 & 3 & 3 & 2 \\
\hline $\mathbf{8}$ & 3 & 3 & 3 & 2 \\
\hline $\mathbf{9}$ & 3 & 3 & 3 & 3 \\
\hline $\mathbf{1 1}$ & 3 & 3 & 3 & 2 \\
\hline $\mathbf{1 2}$ & 3 & 3 & 3 & $\mathbf{2 , 1 7}$ \\
\hline Середнє арифм. & 3 & 3 & 3 & 3 \\
\hline В
\end{tabular}

Відобразимо результати за показниками організаційного критерію для кожного ХОЗН БД (табл. 10).

Таблиия 10

Організаційний критерій та його показники добору ХОЗ у навчанні БД студентів закладів вищої освіти

\begin{tabular}{|c|c|c|c|c|c|}
\hline \multirow[b]{2}{*}{ ХОЗН БД } & \multicolumn{2}{|c|}{ доступність } & \multirow[b]{2}{*}{ 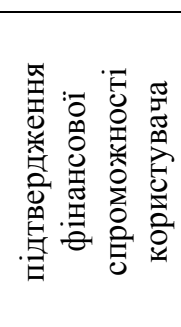 } & \multirow{2}{*}{ 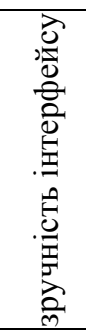 } & \multirow[b]{2}{*}{ 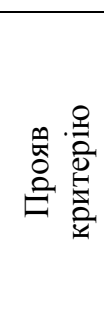 } \\
\hline & 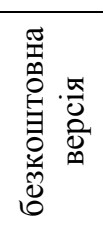 & 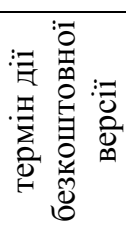 & & & \\
\hline Google Cloud SQL & 2,83 & 1,25 & 0,25 & 1,42 & $25 \%$ \\
\hline Microsoft SQL Azure & 2,92 & 1,00 & 0,17 & 1,75 & $50 \%$ \\
\hline SQLite Viewer with Google Drive & 2,92 & 3,00 & 3,00 & 2,17 & $100 \%$ \\
\hline Google Cloud SQL & 2,83 & 1,25 & 0,25 & 1,42 & $25 \%$ \\
\hline
\end{tabular}


Нагадаємо, що показник вважається позитивним, якщо середнє арифметичне значення вказаних балів показника більше за 1,5. Нижче подаємо підсумкову таблицю результатів прояву всіх критеріїв для обраних ХОЗН БД для підготовки студентів закладів вищої освіти (табл. 11).

Таблиия 11

Результати прояву всіх критеріїв в обраних ХОЗН БД

\begin{tabular}{|l|c|c|}
\hline \multicolumn{1}{|c|}{ Критерій } & Функціонально-дидактичний & Організаційний \\
\hline ХОзн Бд & $100 \%$ & $25 \%$ \\
\hline Microsoft SQL Azure & $100 \%$ & $50 \%$ \\
\hline $\begin{array}{l}\text { SQLite Viewer with Google } \\
\text { Drive }\end{array}$ & $100 \%$ & $100 \%$ \\
\hline
\end{tabular}

Отже, у результаті проведеного експертного оцінювання відібраних ХОЗН БД для підготовки студентів закладів вищої освіти обрано для використання SQLite Viewer with Google Drive y 3BO.

\section{4. ВИСНОВКИ ТА ПЕРСПЕКТИВИ ПОДАЛЬШИХ ДОСЛІДЖЕНЬ}

Відповідно до поставленої мети дослідження було застосовано метод експертного оцінювання, що складався з двох етапів: на першому здійснено опитування експертів для обрання основних ХОЗН БД; на другому визначено ХОЗН БД щодо виокремлених критеріїв добору, що доцільно впроваджувати в навчання БД у ЗВО.

У результаті виділено наступні критерії та відповідні показники добору таких засобів навчання баз даних студентів:

- функціонально-дидактичний: можливість створення, редагування та видалення таблиць у БД; визначення первинних та зовнішніх ключів у таблиці; створення зв'язків між таблицями БД; модифікація даних у таблицях БД; можливість аналізу результатів та помилок у запитах;

- організаційний: доступність (безкоштовна версія; термін дії безкоштовної версії); підтвердження фінансової спроможності користувача; зручність інтерфейсу.

У результаті опрацювання методу експертного оцінювання з'ясовано, що найбільш доцільним хмаро орієнтованим засобом навчання баз даних студентів закладів вищої освіти за проявом усіх критеріїв $\epsilon$ SQLite Viewer with Google Drive.

Перспективним напрямом подальшого дослідження $\epsilon$ розробка методики використання хмаро орієнтованих засобів навчання баз даних студентів закладів вищої освіти.

\section{СПИСОК ВИКОРИСТАНИХ ДЖЕРЕЛ}

[1] В. Ю. Биков, "Технології хмарних обчислень, ІКТ-аутсорсінг та нові функції ІКТ-підрозділів навчальних закладів і наукових установ", Інформаційні технологї в освіті, №10, с. 8-23, 2011.

[2] С. Г. Литвинова, "Теоретико-методичні основи проектування хмаро орієнтованого навчального середовища загальноосвітнього навчального закладу", дис. докт. пед. наук, Інститут інформаційних технологій та засобів навчання, Київ, 2016.

[3] Ю. Г. Носенко, "Інтеграція LMS Moodle з хмарним сервісом Microsoft Office 365: нові можливості для підтримки відкритої освіти" [Електронний ресурс]. Доступно: 
http://lib.iitta.gov.ua/9367/1/Moodle\%20\%282015\%29-

$\% \mathrm{D} 0 \% \mathrm{~B} 4 \% \mathrm{D} 0 \% \mathrm{BE} \% \mathrm{D} 0 \% \mathrm{BF} \% \mathrm{D} 0 \% \mathrm{BE} \% \mathrm{D} 0 \% \mathrm{~B} 2 \% \mathrm{D} 1 \% 96 \% \mathrm{D} 0 \% \mathrm{~B} 4 \% \mathrm{D} 1 \% 8 \mathrm{C} . \mathrm{pdf}$.

[4] В. П. Олексюк, "Досвід інтеграції хмарних сервісів GOOGLE APPS у інформаційно-освітній простір вищого навчального закладу", Інформаційні технологї̈ $і$ засоби навчання, № 3(35), с. 6473, 2013.

[5] М. В. Попель, "Хмарний сервіс Sagemathcloud як засіб формування професійних компетентностей вчителя математики", дис. канд. пед. наук, Інститут інформаційних технологій та засобів навчання, Київ, 2017.

[6] С. О. Семеріков, О. В. Мерзликін, "Перспективні хмарні технології в освіті", Хмарні технологї в сучасному університеті (ХТСУ-2015): тези доп. наук.-практ. семінару, присвяч. 55-річчю від дня заснування ЧДТУ, Черкаси, с. 31-33, 2015.

[7] А. М. Стрюк, М.В. Рассовицька, "Система хмаро орієнтованих засобів навчання як елемент інформаційного освітнь--наукового середовища 3ВО", Інформаційні технологї $і$ засоби навчання, № 4 (42), c. 150-158, 2014.

[8] М. П. Шишкіна, "Теоретико-методичні засади формування i розвитку хмаро орієнтованого освітньо-наукового середовища вищого навчального закладу", дис. д-ра пед. наук, Ін-т інформаційних технологій та засобів навчання, Київ, 2016.

[9] Г. А. Гайна, Основи проектування баз даних: навч. посібник. Київ, КНУБА, 2005.

[10] Л. С. Глоба, М. Ю. Тернова, Р. Л. Новогрудська, О. С. Штогрина, Створення та обробка баз даних: навч. посібник для студ. техн. спец. вищ. навч. закл., Київ, НТУ України "КПІ", 2013.

[11] В. М. Гужва, Інформаційні системи і технології на підприємствах: навч. посібник. Київ, КНЕУ, 2001.

[12] І. О. Завадський, Основи баз даних: навч. посібник. Київ, I. О. Завадський, 2011.

[13] С. В. Шаров, В. В. Осадчий. Бази даних та інформаційні системи : навч. посібник. Мелітополь, МДПУ ім. Б. Хмельницького, 2014.

[14] О. К. Пандорін, Методичні рекомендації до виконання лабораторних робіт з навчальної дисципліни "Принципи проектування баз даних та баз знань" для студентів напряму підготовки 6.051501 "Видавничо-поліграфічна справа" всіх форм навчання, Харків, ХНЕУ ім. С. Кузнеця, 2015.

[15] В. Ю. Биков, О. М. Спірін, Л. А. Лупаренко, “Відкриті web-орієнтовані системи моніторингу впровадження результатів науково-педагогічних досліджень”, Теорія $і$ практика управління сочіальними системами, № 1, с. 3-25, 2014.

[16] В. М. Дем'яненко, Г. П. Лаврентьєва, М. П. Шишкіна, "Методичні рекомендації щодо добору і застосування електронних засобів та ресурсів навчального призначення", Комп'ютер у школі та сім'ї, № 1, с. 44-48, 2013.

[17] К. Р. Колос, "Модель процесу та критерії добору компоннетів комп'ютерно орієнтованого навчального середовища закладу післядипломної педагогічної освіти", Інформаційні технологї в освіті, №17, с. 109-117, 2013.

[18] Л. А. Лупаренко, "Використання електронних журнальних систем відкритого доступу для випуску науково-освітніх видань: порівняльний аналіз програмного забзпечення", Інформаційні технології i засоби навчання, №5 (25), 2011. [Електронний ресурс]. Доступно: http://journal.iitta.gov.ua/index.php/itlt/article/view/573/449.

[19] О. М. Спірін, Т. А. Вакалюк, ”Критерії добору відкритих web-орієнтованих технологій навчання основ програмування майбутніх учителів інформатики", Інформаційні технології $i$ засоби навчання, № 4 (60), с. 275-287, 2017.

[20] С. Д. Бешелев, Ф. Г. Гурвич, Математико-статистические методы экспертных оценок. Москва, Статистика, 1980.

[21] Т. А. Вакалюк, “Критерії добору хмаро орієнтованої системи підтримки навчання як складової хмаро орієнтованого навчального середовища для підготовки бакалаврів інформатики”, Вісник Житомирського державного університету імені Івана Франка, № 4 (90). с. 27-32, 2017.

Матеріал надійшов до редакиії 05.02.2019 p.

\section{ОТБОР ОБЛАКО ОРИЕНТИРОВАННЫХ СРЕДСТВ ОБУЧЕНИЯ БАЗ ДАННЫХ БУДУЩИХ СПЕЦИАЛИСТОВ ПО ИНФОРМАЦИОННЫМ ТЕХНОЛОГИЯМ}

Вакалюк Татьяна Анатольевна

кандидат педагогических наук, доцент, доцент кафедры прикладной математики и информатики 
Житомирский государственный университет имени Ивана Франко, г. Житомир, Украина ORCID ID 0000-0001-6825-4697

neota@zu.edu.ua

\title{
Коротун Ольга Владимировна
}

кандидат педагогических наук, старший преподаватель кафедры компьютерных наук Житомирский государственный технологический университет, г. Житомир, Украина ORCID ID 0000-0003-2240-7891

olgavl.korotun@gmail.com

\section{Антонюк Дмитрий Сергеевич}

кандидат педагогических наук, доцент кафедры инженерии программного обеспечения Житомирский государственный технологический университет, г. Житомир, Украина ORCID ID 0000-0001-7496-3553

dmitry_antonyuk@zu.edu.ua

\begin{abstract}
Аннотация. В статье осуществлен отбор облако ориентированных средств обучения баз данных студентов высших учебных заведений методом экспертной оценки. Для этого выделены критерии и соответствующие показатели отбора указанных средств обучения. Из предложенных облако ориентированных средств обучения баз данных (Amazon RDS, Google Cloud SQL, Heroku PostgreSQL, Microsoft SQL Azure, Oracle Database Cloud Service, Rackspace Cloud Databases, SQLite Viewer) были выбраны три методом экспертного оценивания, к которому было привлечено преподавателей, заведующих кафедрами и деканов высших учебных заведений Украины, которые имеют опыт работы в учреждениях высшего образования и непосредственно связаны с обучением баз данных. Проведен сравнительный анализ имеющихся облако ориентированных средств обучения баз данных, a именно: Google Cloud SQL, Microsoft SQL Azure, SQLite Viewer with Google Drive, который позволил определить функционально-дидактический и организационный критерии. Рассмотрены возможности применения таких облако ориентированных средств обучения студентов в учреждениях высших учебных заведениях. К каждому из указанных критериев были выделены соответствующие показатели. К функционально-дидактическому критерию отнесены: возможность создания, редактирования и удаления таблиц в базах данных; определение первичных и внешних ключей в таблице; создание связей между таблицами баз данных; модификация данных в таблицах баз данных; возможность анализа результатов и ошибок в запросах. К организационному относятся показатели: доступность (бесплатная версия, срок действия бесплатной версии), подтверждение финансовой состоятельности пользователя; удобство интерфейса. В результате применения метода экспертной оценки установлено, что наиболее целесообразным облако ориентированным средством обучения баз данных студентов высших учебных заведений за проявлением всех критериев является SQLite Viewer with Google Drive.
\end{abstract}

Ключевые слова: отбор; критерии отбора; облако ориентированные средства; базы данных; студенты высших учебных заведений.

\section{SELECTION OF THE CLOUD-ORIENTED DATABASE LEARNING TOOLS FOR FUTURE IT PROFESSIONALS}

\section{Tetiana A. Vakaliuk}

$\mathrm{PhD}$ of Pedagogical Sciences, Associate Professor

Associate Professor of the Department of Applied Mathematics and Computer Science

Zhytomyr Ivan Franko State University, Zhytomyr, Ukraine

ORCID ID 0000-0001-6825-4697

neota@zu.edu.ua

\section{Olha V. Korotun}

PhD of Pedagogical Sciences, Associate Professor of the Department of Computer Science Zhytomyr State Technological University, Zhytomyr, Ukraine

ORCID ID 0000-0003-2240-7891

olgavl.korotun@gmail.com 


\title{
Dmytro S. Antoniuk
}

PhD of Pedagogical Sciences, Associate Professor of the Department of Software Engineering Zhytomyr State Technological University, Zhytomyr, Ukraine

ORCID ID 0000-0001-7496-3553

dmitry_antonyuk@yahoo.com

\begin{abstract}
The article describes the selection of cloud-oriented learning tools for educational process of the students of higher education establishments by the expert appraisal method. The criteria and appropriate indicators for learning tool selection have been defined. Three learning tools to study databases were selected out of the list of offered tools, such as: Amazon RDS, Google Cloud SQL, Heroku PostgreSQL, Microsoft SQL Azure, Oracle Database Cloud Service, Rackspace Cloud Databases, SQLite Viewer. The expert appraisal method has been used with involvement of teachers, lecturers, departments' heads and deans that have experience in teaching databases at the Ukrainian higher education establishments. The comparing analysis of the cloudoriented database learning tools, such as Google Cloud SQL, Microsoft SQL Azure, SQLite Viewer with Google Drive, has been conducted. The functionally-didactical and organizational criteria were defined. The possibility to use such cloud-oriented learning tools in the higher education establishments were examined. Appropriate indicators for each criterion were defined. The functionally-didactical criterion has the next indicators: possibility to create, to edit and drop tables in the databases; finding the primary and external keys for the tables; creation the connections for the tables in the databases; data modification in the tables of databases; functionality to analyze the results and errors of the queries execution in the databases. The organizational criterion has the following indicators: affordability (presence of the free of charge version; validity term for the free of charge version); need in the financial ability of the customer prove; customer interface usability. As the result of the expert appraisal selection method, has been revealed that SQLite Viewer with Google Drive is the most reasonable learning tool, by the manifestation of all the criteria, for the students of higher education establishments.
\end{abstract}

Keywords: selection; selection criteria; cloud-oriented tools; databases; students of higher education establishments.

\section{REFERENCES (TRANSLATED AND TRANSLITERATED)}

[1] V. Yu. Bykov, "Cloud computing technologies, ICT outsourcing and new functions of ICT subdivisions of educational institutions and research institutions ", Information Technologies in Education, №10, p. 823, 2011. (in Ukrainian)

[2] S. H. Lytvynova, "Theoretical and methodological bases of designing of cloud-oriented educational environment of a comprehensive educational institution", dissertation of the Doctor of Pedagogical Sciences, Institute of Information Technologies and Means of Education, Kyiv, 2016. (in Ukrainian)

[3] Yu. H. Nosenko, "Integration of LMS Moodle with Microsoft Office 365 Cloud Service: New Opportunities for Open Education Support" [online]. Available: http://lib.iitta.gov.ua/9367/1/Moodle\%20\%282015\%29$\% \mathrm{D} 0 \% \mathrm{~B} 4 \% \mathrm{D} 0 \% \mathrm{BE} \% \mathrm{D} 0 \% \mathrm{BF} \% \mathrm{D} 0 \% \mathrm{BE} \% \mathrm{D} 0 \% \mathrm{~B} 2 \% \mathrm{D} 1 \% 96 \% \mathrm{D} 0 \% \mathrm{~B} 4 \% \mathrm{D} 1 \% 8 \mathrm{C}$.pdf. (in Ukrainian)

[4] V. P. Oleksiuk, "The Experience of Integrating GOOGLE APPS Cloud Services in the Information and Educational Space of Higher Educational Institutions", Information Technologies and Learning Tools, № 3(35), p. 64-73, 2013. (in Ukrainian)

[5] M. V. Popel', "Cloud service Sagemathcloud as a means of forming the professional competencies of the teacher of mathematics", diss. Cand. ped Sciences, Institute of Information Technologies and Learning Tools, Kyiv, 2017. (in Ukrainian)

[6] S. O. Semerikov, O. V. Merzlykin, "Perspective cloud technologies in education", Cloud technologies in modern university (CTMU-2015): abstracts of additional. sci. pract. a seminar devoted to The 55th anniversary of the foundation of the ChTTU, Cherkasy, p. 31-33, 2015. (in Ukrainian)

[7] A. M. Striuk, M. V. Rassovyts'ka, "The system of cloud-oriented teaching aids as an element of the informational educational and scientific environment of the IHE", Information technology and learning tools, № 4 (42), p. 150-158, 2014. (in Ukrainian)

[8] M. P. Shyshkina, "Theoretical and methodical principles of formation and development of the cloudoriented educational and scientific environment of a higher educational establishment", diss. Dr. Ped. Sciences, Institute of Information Technologies and Learning, Kyiv, 2016. (in Ukrainian)

[9] H. A. Haina, Basics of database design: tutor. manual. Kyiv, KNUBA, 2005. (in Ukrainian) 
[10] L. S. Hloba, M. Yu. Ternova, R. L. Novohruds'ka, O. S. Shtohryna, Creating and processing databases: tutorials. student guide tech special higher teach eng., Kiev, NTU of Ukraine "KPI", 2013. (in Ukrainian)

[11] V. M. Huzhva, Information systems and technologies at the enterprises: teaching. manual. Kyiv, KNEU, 2001. (in Ukrainian)

[12] I. O. Zavads'kyi, Database basics: tutor. manual. Kyiv, I.O. Zavadsky, 2011. (in Ukrainian)

[13] S. V. Sharov, V. V. Osadchyi, Databases and Information Systems: Teaching. manual. Melitopol, MDPU them. B. Khmelnitsky, 2014. (in Ukrainian)

[14] O. K. Pandorin, Methodical recommendations for the implementation of laboratory work in the discipline "Principles of designing databases and knowledge bases" for students of the direction of preparation 6.051501 "Publishing and printing business" of all forms of education, Kharkiv, KhNEU them. S. Kuznets, 2015. (in Ukrainian)

[15] V. Yu. Bykov, O. M. Spirin, L. A. Luparenko, "Open web-based systems of scientific and educational research implementation monitoring", Theory and practice of social systems management, № 1, p. 3-25th, 2014. (in Ukrainian)

[16] V. M. Demyanenko, G. P. Lavrentyev, M. P. Shishkina, "Methodical recommendations on the selection and use of electronic resources and resources for educational purposes", Computer at school and family, No. 1, with. 44-48, 2013. (in Ukrainian)

[17] K. R. Kolos, "Model process and criteria for selection of components computer oriented training environment postgraduate teacher education", Information Technologies in Education, No. 17, p. 109117, 2013. (in Ukrainian)

[18] L. A. Luparenko, "Use of electronic open access journal systems for release of research educational edition: software comparative analysis", Information Technologies and Learning Tools, №5 (25), 2011. [online]. Available: http://journal.iitta.gov.ua/index.php/itlt/article/view/573/449. (in Ukrainian)

[19] O. M. Spirin, T. A. Vakaliuk, "Criteria of open web-operated technologies of teaching the fundamentals of programs of future teachers of informatics", Information Technologies and Learning Tools, No. 4 (60), p. 275-287, 2017. (in Ukrainian)

[20] S. D. Beshelev, F. G. Gurvich, Mathematical-statistical methods of expert evaluations. Moscow, Statistics, 1980. (in Russian)

[21] T. A. Vakaliuk, "Criteria for Selecting a Cloud-Based Learning Support System as a Part of Cloud-Based Learning Environment for Bachelor's Degree in Computer Science", Bulletin of Zhytomyr State University named after Ivan Franko, No. 4 (90). with. 27-32, 2017. (in Ukrainian)

\section{$(c)$ BY-NC-SA}

This work is licensed under Creative Commons Attribution-NonCommercial-ShareAlike 4.0 International License. 